\title{
KETOKSIKAN SUBKRONIS NANOPARTIKEL EKSTRAK ETANOL BUAH MAHKOTA DEWA (Phaleria macrocarpa (Scheff.) Boerl.) DAN GAMBARAN HISTOPATOLOGIK HEPAR PADA MENCIT JANTAN GALUR BALB-C
}

\author{
SUBCHRONIC TOXICITY OF NANOPARTICLE FROM ETHANOLIC EXTRACT \\ MAHKOTA DEWA (Phaleria macrocarpa (Scheff.) Boerl.) AND HISTOPATHOLOGIC \\ PROFILE HEPAR IN MALE STRAIN BALB-C MICE
}

Kartika Rakhmawati, Iis Wahyuningsih*

Fakultas Farmasi Universitas Ahmad Dahlan

Jl. Prof. Dr. Soepomo Janturan Umbulharjo Yogyakarta 55164

*Penulis Korespodensi, email: iis.wahyuningsih@pharm.uad.ac.id

\begin{abstract}
ABSTRAK
Buah mahkota dewa (Phaleria macrocarpa (Scheff.) Boerl.) memiliki khasiat sebagai obat antikanker. Namun konsumsi berulang buah mahkota dewa dapat menyebabkan efek toksik pada organ ekskresi dan metabolisme. Preparasi nanopartikel ekstrak mahkota dewa dibuat dengan tujuan menurunkan efek toksik dari mahkota dewa. Penelitian eksperimental dengan rancangan the post test only control group design. Jumlah sample 35 ekor mencit Balb-c yang dibagi dalam 7 kelompok secara acak. Kelompok kontrol (I) hanya diberi CMC Na 0,5\%, kelompok perlakuan II-IV masing-masing, secara berurutan, diberi ekstrak etanol buah mahkota dewa dosis 85, 170, dan $340 \mathrm{mg} / \mathrm{KgBB}$. Kelompok perlakuan V-VII masing-masing, secara berurutan, diberi nanopartikel ekstrak buah mahkota dewa dosis setara dengan flavonoid 85, 170, dan $340 \mathrm{mg} / \mathrm{KgBB}$. Hasil penelitian menunjukkan perlakuan kelompok hewan yang diberi ekstrak dengan dosis $85,170,340 \mathrm{mg} / \mathrm{KgBB}$ menunjukkan adanya degenerasi hidropik pada sel hepar, infiltrasi sel radang hingga nekrosis. Begitu juga pada mencit yang diberikan nanopartikel, akan tetapi pada mencit yang diberi nanopartikel ada beberapa hewan uji yang heparnya normal. Probabilitas penurunan kerusakan dari dosis 85 , 170, dan 340mg/KgBB yaitu sebesar 0,2; 04; dan 0;4. Kesimpulan penelitian ini nanopartikel ekstrak etanol buah mahkota dewa dapat menurunkan kejadian kerusakan hepar pada hewan uji dibandingkan dengan ekstrak etanol buah mahkota dewa saja.
\end{abstract}

Kata kunci: toksisitas subkronik, hepar, nanopartikel , ekstrak , mahkota dewa

\section{ABSTRACT}

Mahkota dewa (Phaleria macrocarpa (Scheff.) Boerl.) has efficacy as an anticancer drug. But the repeated consumption of mahkota dewa can cause toxic effects on excretion and metabolism. Modified nanoparticles extracts mahkota dewa was made to decrease its toxicity effects. Experimental research was design by the post-test only control group design. Number of samples 35 mice Balb-c are divided into 7 groups randomly. The control group (I) was given only $0.5 \% \mathrm{CMC} \mathrm{Na}$, II-IV treatment groups, are given the ethanolic extract of mahkota dewa fruit with a dose 85, 170, and $340 \mathrm{mg} / \mathrm{BW}$. Treatment V-VII groups respectively, in order, given nanoparticle ethanolic extract of mahkota dewa with a dose equal to flavonoid 85, 170, and $340 \mathrm{mg} / \mathrm{BW}$. Results the treatment group of animals treated with the extract at a dose of $85,170,340 \mathrm{mg} / \mathrm{BW}$ weight showed hydropic degeneration of 
liver cells, infiltration of inflammatory cells to necrosis. And also in mice given by nanoparticles, but there are some animals that have normal hepar. The decrease of damage probability from doses 85,170 , and $340 \mathrm{mg} / \mathrm{BW}$ is equal to 0.2; 04; and 0 ; 4 . The conclution is that nanoparticles of ethanol extract of mahkota dewa can reduce the incidence of liver damage compared with just ethanol extract of the fruit mahkota dewa alone in animals test.

Keywords: toxicity, hepar, nanopartcle, ethanolic extract, mahkota dewa fruits

\section{PENDAHULUAN}

Penggunaan obat tradisional atau jamu di Indonesia terus meningkat, ditandai dengan bertambah banyaknya industri jamu atau farmasi yang memproduksi obat tradisional atau jamu. Obat tradisional harus dikonsumsi dengan tepat agar memberikan hasil yang baik. Ketepatan itu menyangkut tepat dosis, cara, dan waktu penggunaan serta pemilihan bahan ramuan yang sesuai dengan indikasi penggunaannya (Katno dan Pramono, 2004).

Salah satu obat tradisional yang populer di kalangan masyarakat adalah mahkota dewa (Phaleria macrocarpa (Scheff.) Boerl.). Mahkota dewa merupakan tanaman obat yang berasal dari Papua. Pada pengujian efek sitotoksisitas dengan cara Brine Shrimp Lethality Test (BSLT) menggunakan Artemia salina Leach menunjukkan bahwa nilai IC50 ekstrak etanol dari mahkota dewa adalah $0,123 \mathrm{ug} / \mathrm{ml}$ (Radji et al., 2008). Akan tetapi pada setiap penggunaan obat harus diperhatikan ketepatan dosisnya. Begitu juga dalam penggunaan buah mahkota dewa. Dosis yang tidak tepat dapat menyebabkan ketoksikan dalam tubuh. Pengobatan kanker merupakan pengobatan jangka panjang sehingga perlu dilihat toksisitas jangka panjang dari buah mahkota dewa. Berdasarkan penelitian sebelumnya telah diketahui bahwa mahkota dewa dapat menyebabkan disfungsi parenkim berupa vakuolisasi sitoplasma pada jaringan hepar mencit pada pemberian dosis $170 \mathrm{mg} / \mathrm{KgBB}$ (Soeksmanto, 2006).

Untuk mengurangi toksisitas dan efek samping yang berat dari tanaman mahkota dewa, salah satu cara adalah dengan meningkatkan selektifitasnya. Yaitu dengan menjerap ekstrak buah mahkota dewa dalam bentuk nanopartikel sebagai sistem penghantaran obat yang tertarget. Nanopartikel banyak digunakan sebagai sistem penghantaran obat karena memiliki berbagai macam keuntungan, antara lain kemampuan masuk ke dalam sel dan kemampuan melepaskan obat dengan kecepatan, dosis, dan target yang tepat sehingga diharapkan dapat meningkatkan efek terapetik serta mengurangi toksisitas (Mohanraj dan Chen, 2006).Tujuan penelitian ini adalah mengetahui pengaruh pembentukan nanopartikel ekstrak etanol buah mahkota dewa terhadap ketoksikan subkronis pada hepar mencit jantan galur Balb-c.

\section{METODE PENELITIAN}

\section{Bahan dan Alat}

Bahan yang digunakan dalam penelitian ini adalah buah mahkota dewa (Phaleria macrocarpa (Scheff.) Boerl), Kitosan (Sigma Aldrich ${ }^{\circledR}$ ), TPP (Sigma Aldrich ${ }^{\circledR}$ ), Asam asetat p.a., Na-Asetat, air bebas $\mathrm{CO}_{2}$. Etanol 70\% (Merck), Formalin teknis 10\%, akuades, dan CMC-Na. Hewan uji yang digunakan adalah mencit putih jantan (Mus musculus), galur Balb$c$, usia 2-3 bulan, dengan bobot badan berkisar antara 20 sampai 30 gram. 
Peralatan yang digunakan dalam penelitian ini adalah alat-alat gelas (Pyrex), timbangan elektrik (Ohaus carat series), soxhlet (Pyrex), rotary evaporator (Heidolph Germany), mikropipet (pipet PAL), $\mathrm{pH}$ meter, hotplate stirrer (Thermo scientific cimarec), waterbath (Memmert), ultrasonic bath (Elmasonic $\mathrm{S} 30 \mathrm{H}$ ), , ultra sentrifuge (Hettich zentrifugen mikro $220 \mathrm{R}$ ), peralatan bedah (pinset, gunting bedah, jarum), mikroskop untuk memeriksa hispatologik, dan beberapa kandang mencit.

\section{Jalannya Penelitian}

\section{Identifikasi Buah Mahkota Dewa}

Identifikasi buah mahkota dewa dilakukan di Laboratorium Biologi Fakultas Matematika dan Ilmu Pengetahuan Alam Universitas Ahmad Dahlan Yogyakarta menggunakan buku "Farmakope Herbal Indonesia".

\section{Penyiapan Simplisia}

Buah mahkota dewa yang dipilih adalah yang tua, berwarna merah marun (Mudahar et al., 2005). Buah mahkota dewa diiris tipis kemudian dikeringkan dengan cara dioven selama 24 jam. Kemudian dihaluskan dengan alat pemotong atau penggiling hingga menjadi serbuk yang halus (Sulistianto et al., 2004).

\section{Pembuatan Ekstrak Etanol Buah Mahkota Dewa}

Sampel dihaluskan dengan menggunakan blender, mahkota dewa dipisahkan dengan metode ekstraksi soxhlet (Rohyami, 2008). Masing-masing sebanyak $30 \mathrm{~g}$ sampel daging buah mahkota dewa dibungkus rapat dengan kertas saring dan dimasukkan ke dalam soxhlet. Ekstraksi dilakukan dengan menggunakan soxhlet dengan pelarut etanol, ekstrak etanol yang diperoleh, dipekatkan dengan bantuan vakum raotary evaporator, sehingga didapatkan ekstrak kental (Mudahar et al., 2005).

\section{Pembuatan Nanopartikel}

Larutan hasil redisolvasi ekstrak ditambahkan larutan kitosan lalu diaduk hingga homogen. Larutan TPP ditambahkan ke dalam larutan tetes demi tetes, sambil diaduk (20 menit dengan magnetik stirer $350 \mathrm{rpm}$ ) hingga terbentuk dispersi nanopartikel (opalesens). Selanjutnya dispersi nanopartikel yang dalam bentuk cairan tersebut dibuat menjadi bentuk serbuk dengan bantuan freezedryer. Dispersi nanopartikel dimasukkan ke dalam eppendorf, lalu diultrasentrifus selama 30 menit dengan kecepatan $15000 \mathrm{rpm}$ pada suhu $4^{\circ} \mathrm{C}$. Cairan bening hasil ultrasentrifus dibuang dan disisakan endapannya saja. Endapan pada sejumlah eppendorf tadi dimasukkan kedalam freezer selama 24 jam. Setelah 24 jam endapan dimasukkan dalam freezedryer selama kurang lebih 2 jam hingga terbentuk serbuk nanopartikel.

\section{Pembuatan Suspensi CMC-Na}

CMC Na digunakan sebagai kontrol negarif. Sejumlah CMC-Na ditimbang lalu dikembangkan dengan akuades hangat $70 \mathrm{C}$ sejumlah 20 kali beratnya. Setelah mengembang CMC-Na digerus dengan ditambahkan akuades hingga jumlah tertentu.

Pengelompokan Hewan Uji

Sebanyak 35 ekor mencit dibagi secara acak menjadi 7 kelompok. Setiap kelompok terdiri dari 5 ekor mencit.

Kelompok I : kontrol negatif CMC-Na 0,5\%,

Kelompok II : $85 \mathrm{mg} / \mathrm{KgBB}$ ekstrak buah mahkota dewa 
kelompok III : $170 \mathrm{mg} / \mathrm{KgBB}$ ekstrak buah mahkota dewa

kelompok IV : $340 \mathrm{mg} / \mathrm{KgBB}$ ekstrak buah mahkota dewa

Kelompok V : nanopartikel setara $85 \mathrm{mg} / \mathrm{KgBB}$ flavonoid ekstrak etanol buah mahkota dewa

kelompok VI : nanopartikel setara $170 \mathrm{mg} / \mathrm{KgBB}$ flavonoid ekstrak etanol buah mahkota dewa

kelompok VII : nanopartikel setara $340 \mathrm{mg} / \mathrm{KgBB}$ flavonoid ekstrak etanol buah mahkota dewa.

Perlakuan dilakukan selama 14 hari. Obat diberikan secara peroral terhadap hewan uji.

Pemeriksaan Histopatologik

Pada akhir masa uji semua hewan uji pada masing-masing kelompok dikorbankan secara fisik dengan cara dislokasi leher. Setelah dibedah, diambil organ yang akan dilakukan pengamatan yaitu hepar. Organ tersebut dicuci dengan $\mathrm{NaCl}$ 0,9\% dan difiksasi dengan larutan formalin 10\% kemudian dikirim ke laboratorium Patologi Anatomi Fakultas Kedokteran Hewan Universitas Gajah Mada untuk pembuatan preparat histopatologik.

\section{Analisis Data}

Data yang digunakan pada analisis hasil adalah data kualitatif dan data kuantitatif. Data kualitatif berupa data pemeriksaan gejala klinis maupun hispatologik hepar, kemudian dibandingkan terhadap kelompok kontrol. Data kuantitatif berupa berat badan hewan uji dan bobot tiap-tiap organ, diuji normalitas dan homogenitasnya dengan Kolmogorov-Smirnov untuk menentukan uji statistika menggunakan parametrik atau non parametrik. Jika data terdistribusi normal dan variannya homogen maka uji statistika menggunakan parametrik dengan anova satu jalan dengan taraf kepercayaan $95 \%$.

\section{HASIL DAN PEMBAHASAN}

\section{Identifikasi Buah Mahkota Dewa (Phaleria macrocarpa)}

Identifikasi buah mahkota dewa dilakukan untuk menghindari adanya kesalahan saat pengambilan bahan penelitian dan menjamin kebenaran dari objek bahan yang digunakan dalam penelitian. Hasil pengamatan menunjukkan adanya persamaan pengamatan mikroskopik sampel dengan teori yaitu terdapat penebalan cincin dan noktah pada berkas pengangkut serta terdapat jaringan parenkim dari simplisia/serbuk buah mahkota dewa yang digunakan.

\section{Pembuatan Ekstrak Mahkota Dewa}

Buah mahkota dewa mula-mula dibelah lalu bijinya dipisahkan dan kemudian diiris tipis. Irisan buah segera dikeringkan dengan menggunakan oven agar pengeringannya merata dan tidak terpengaruh cahaya matahari. Metode yang digunakan dalam membuat ekstrak mahkota dewa yaitu metode soxhletasi (Rohyami, 2008). Ekstrak buah mahkota dewa diamati secara organoleptis. Yaitu berupa ekstrak kental dengan konsistensi yang lunak, lengket, berwarna hitam kecoklatan, dan berbau aroma khas mahkota dewa. Dari 90 gram serbuk buah mahkota dewa diperoleh ekstrak kental sebanyak 8,19 gram sehingga diperoleh nilai rendemen $9,11 \%$. 


\section{Pembuatan Nanopartikel Ekstrak Etanol Buah Mahkota Dewa}

Berdasarkan penelitian yang dilakukan oleh Nafsah (2014) pembuatan nanopartikel ekstrak etanol buah mahkota dewa dilakukan dengan metode gelasi ionik menggunakan polimer kitosan dan crosslinker TPP. Larutan ekstrak dibuat dengan konsentrasi $2 \mathrm{mg} / \mathrm{mL}$ dalam etanol $70 \%$, kitosan $0,2 \%$ dalam dapar asetat $\mathrm{pH} 4$, dan TPP 0,2\% dalam akuades bebas $\mathrm{CO}_{2}$. Larutan ekstrak dan kitosan dengan volume sama banyak diaduk selama 30 menit menggunakan magnetic stirer. Kemudian ditambahkan TPP tetes per tetes sambil dihomogenkan selama 30 menit agar terjadi ikatan polielektrolit antara kitosan yang bermuatan positif dan TPP yang bermuatan negatif (Mardliyati et al., 2012). Preparasi nanopartikel ekstrak etanol buah mahkota dewa menghasilkan dispersi nanopartikel oppalens dengan diameter rata-rata $162,87 \mathrm{~nm}$. Total nanopartikel serbuk yang diperoleh 30,9 gram. Selain itu diperoleh nilai Loading Capacity 5,34\% dan Loading Efficiency 45,26\%.

Pengamatan Gejala Klinik

Gejala klinik merupakan gejala fisik yang muncul setelah pemberian obat dan gejala tersebut dapat diamati secara visual. Pengamatan kualitatif terhadap gejala-gejala klinik yang mungkin timbul dilakukan selama 2 jam setelah pemberian ekstrak. Tabel pengamatan gejala klinik tersaji dalam Tabel I.

Tabel I. Pengamatan gejala klinik mecit selama 14 hari setelah perlakuan.

\begin{tabular}{lccccc}
\hline & \multicolumn{5}{c}{ Gejala Klinik } \\
\cline { 2 - 6 } Kelompok & $\begin{array}{c}\text { Perilaku } \\
\text { Gerakan }\end{array}$ & $\begin{array}{c}\text { Kereaktifan } \\
\text { Rangsangan }\end{array}$ & $\begin{array}{c}\text { Ukuran } \\
\text { Pupil }\end{array}$ & $\begin{array}{c}\text { Konsistensi dan Warna } \\
\text { Feses }\end{array}$ & $\begin{array}{c}\text { Keadaan } \\
\text { Fisik Kulit }\end{array}$ \\
\hline Kontrol & - & - & - & - & - \\
EEBMD 85 mg/KgBB & - & - & - & - & - \\
EEBMD 170 mg/KgBB & - & - & - & - & - \\
EEBMD 340 mg/KgBB & - & - & - & - & - \\
NEEBMD 85 mg/KgBB & - & + & - & - & - \\
NEEBMD 170 mg/KgBB & - & + & - & - & - \\
NEEBMD 340 mg/KgBB & - & + & - & - & - \\
\hline
\end{tabular}

Keterangan :

(-) : : Tidak ada perubahan

$(+) \quad$ : Ada perubahan

EEBMD : Ekstrak etanol buah mahkota dewa

NEEBMD : Nanopartikel ekstrak etanol buah mahkota dewa

\section{Pemeriksaan Makroskopik Organ Hepar}

Pada pemeriksaan makroskopik dilakukan pengamatan terhadap kondisi masingmasing organ hepar dengan tujuan untuk melihat apakah terdapat perubahan morfologi dari organ tersebut. Pengamatan makroskopik dilakukan terhadap masing-masing kelompok perlakuan yang kemudian dibandingkan dengan kelompok kontrol. Gambaran makroskopi hepar mencit tersaji pada Gambar 1 dan Tabel II.

Dari hasil pengamatan organ hepar pada Gambar 1 dan Tabel II, hepar terlihat normal, bertekstur kenyal, berwarna merah tua, terdiri dari beberapa lobulus, dan tidak terlihat adanya kelainan morfologi. Tidak dijumpai adanya kelainan atau perbedaan yang berarti baik dari kelompok kontrol maupun kelompok perlakuan. 


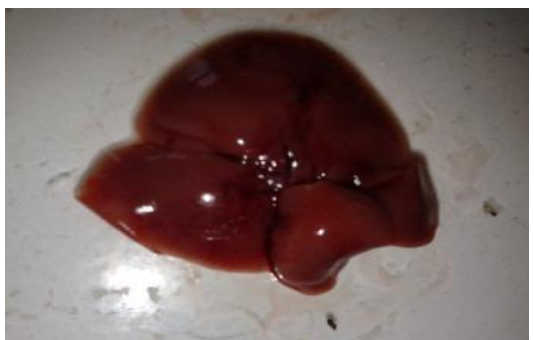

Gambar 1. Makroskopi hepar mencit setelah perlakuan pada kelompok V

Tabel II. Hasil pengamatan makroskopi organ hepar

\begin{tabular}{cccccccc}
\hline Mencit & Kontrol & \multicolumn{2}{c}{ Dosis EEBMD (mg/KgBB) } & \multicolumn{2}{c}{ Dosis NEEBMD (mg/KgBB) } \\
\cline { 2 - 7 } & & 85 & 170 & 340 & 85 & 170 & 340 \\
\hline $\mathbf{1}$ & $\mathrm{N}$ & $\mathrm{N}$ & $\mathrm{N}$ & $\mathrm{N}$ & $\mathrm{N}$ & $\mathrm{N}$ & $\mathrm{N}$ \\
\hline $\mathbf{2}$ & $\mathrm{N}$ & $\mathrm{N}$ & $\mathrm{N}$ & $\mathrm{N}$ & $\mathrm{N}$ & $\mathrm{N}$ & $\mathrm{N}$ \\
\hline $\mathbf{3}$ & $\mathrm{N}$ & $\mathrm{N}$ & $\mathrm{N}$ & $\mathrm{N}$ & $\mathrm{N}$ & $\mathrm{N}$ & $\mathrm{N}$ \\
\hline $\mathbf{4}$ & $\mathrm{N}$ & $\mathrm{N}$ & $\mathrm{N}$ & $\mathrm{N}$ & $\mathrm{N}$ & $\mathrm{N}$ & $\mathrm{N}$ \\
\hline $\mathbf{5}$ & $\mathrm{N}$ & $\mathrm{N}$ & $\mathrm{N}$ & $\mathrm{N}$ & $\mathrm{N}$ & $\mathrm{N}$ & $\mathrm{N}$
\end{tabular}

Keterangan :

EEBMD : Ekstrak Etanol Buah Mahkota Dewa

NEEBMD : Nanopartikel Ekstrak Etanol Buah Mahkota Dewa

$\mathrm{N} \quad$ : Normal

\section{Pemeriksaan Berat Badan dan Rasio Berat Organ Hepar}

Pemeriksaan berat badan dan organ ini bertujuan untuk mengetahui adanya perubahan berat badan dan organ setelah perlakuan. Berat organ relatif atau rasio merupakan indeks yang sering digunakan dalam evaluasi toksikologi (Michael et al., 2007). Perubahan berat badan pada hari ke 1-8 terlihat nilai signifikansi $<0,05$, atau ada perbedaan yang signifikan yaitu terdapat peningkatan berat badan mencit. Hal ini dapat disebabkan karena terdapat degenerasi hidropik pada hepar dimana terdapat cairan di dalam sinusoid hepar sehingga berat hepar dan berat badan dimungkinkan dapat meningkat. Pada perubahan berat badan hari ke 8-15 nilai signifikansi yang dihasilkan $>0,05$, hal ini menunjukkan bahwa tidak ada perubahan signifikan pada periode tersebut. Analisis spesifik rasio berat organ diperoleh data bahwa ada perbedaan signifikan antara rasio berat hepar kelompok kontrol dengan kelompok ekstrak etanol buah mahkota dewa, sedangkan rasio berat hepar kelompok kontrol dengan kelompok nanopartikel tidak berbeda signifikan. 


\section{Pemeriksaan Histopatologik}

Toksisitas organ hepar tingkat seluler dapat menyebabkan perubahan histologis dan perubahan fungsional sel-sel hepar (Utomo et al., 2012). Hasil pemeriksaan histopatologik hepar mencit setelah dilakukan pengecatan dengan hematoksin dan eosin tersaji dalam Tabel III. Pada tabel tersebut terlihat semua mencit kelompok kontrol normal, tidak ditemukan kelainan pada sel-sel hepar. Hal ini sesuai dengan teori karena mencit pada kelompok kontrol hanya diberi pelarut obat saja yaitu CMC Na.

Pada kelompok ekstrak etanol buah mahkota terdapat beberapa kerusakan pada jaringan hepar mencit diantaranya terdapat kerusakan berupa degenerasi hidropik pada kelompok dosis $85 \mathrm{mg} / \mathrm{KgBB}$. Degenerasi hidropobik terjadi karena terdapat akumulasi cairan di dalam sitoplasmik sekunder sehingga menganggu integritas membran sel. Akumulasi tersebut menyebabkan sel mengalami pembengkakan cairan. Hal ini dapat disebabkan karena jumlah xenobiotik pada lokasi lobular yang berbeda dan memungkinkan terjadinya nekrosis pada hepatosit (Thoolen, 2010).

Pada kelompok dosis $170 \mathrm{mg} / \mathrm{KgBB}$ terdapat infiltrasi sel radang di sekitar vena sentralis. Infiltrasi sel radang merupakan respon terhadap kematian sel parenkim yang disebabkan oleh agen infeksius, paparan toksikan, metabolisme zat toksik maupun jaringan yang mengalami anoksia. Begitu juga pada kelompok dosis $340 \mathrm{mg} / \mathrm{KgBB}$ juga terdapat infiltrasi sel radang bahkan disertai dengan lisisnya sel hepar. Hal ini menunjukkan bahwa semakin besar dosis yang digunakan terlihat tingkat keparahan yang lebih besar.

Pemeriksaan histopatologik kelompok mencit yang diberi nanopartikel ekstrak etanol buah mahkota dewa yang setara dengan dosis 85,170 , dan $340 \mathrm{mg} / \mathrm{KgBB}$ terlihat jenis kerusakan yang tidak jauh berbeda dengan yang ada pada kelompok mencit ekstrak etanol mahkota dewa. Pada pemberian dosis nanopartikel ekstrak etanol setara dengan $85 \mathrm{mg} / \mathrm{KgBB}$ terlihat adanya multifokal nekrotik di parenkim ditandai dengan adanya area nekrosis. Inti mengalami kariopiknosis sitoplasma hiperesinofilik disertai infiltrasi limfosit di daerah nekrosis. Hal tersebut juga terjadi pada mencit dengan dosis setara 170 dan $340 \mathrm{mg} / \mathrm{KgBB}$. Akan tetapi pada kelompok mencit yang diberi nanopartikel ini terdapat beberapa mencit yang jaringan hatinya normal. Sehingga kemudian dihitung probabilitas/peluang penurunan efek toksik yang timbul setelah pemberian nanopartikel ekstrak etanol. Probabilitas penurunan efek toksik pada kelompok mencit pemberian nanopartikel setara dengan $85 \mathrm{mg} / \mathrm{KgBB}$ sebesar 0,2 terdapat satu hewan uji yang kondisi hepar normal diantara 5 hewan uji yang ada. Pada kelompok dosis 170 dan $340 \mathrm{mg} / \mathrm{KgBB}$ probabilitas penurunan efek toksik sebesar 0,4 yaitu terdapat dua hewan uji yang kondisi heparnya normal diantara lima hewan uji yang ada. Gambaran histopatologik hepar tersaji pada Gambar 2.

Penurunan efek toksik pada kelompok hewan uji yang diberi nanopartikel ekstrak etanol buah mahkota dewa sejalan dengan penelitian yang dilakukan oleh Biazar et al (2010) mengenai efek hepatotoksik nanopartikel acetaminophen pada tikus yang memberikan hasil bahwa secara patologi nanopartikel acetaminophenum dapat menurunkan efek nekrosis jika dibandingkan dengan acetaminophen normal. Perbedaan penurunan efek toksik pada masing-masing hewan uji kelompok nanopatikel terjadi dimungkinkan karena perbedaan kemampuan masing-masing hewan uji dalam memetabolisme zat toksik yang diberikan. Faktor-faktor yang mempengaruhi 
Tabel III. Hasil pemeriksaan mikroskopik hepar mencit

\begin{tabular}{llllll}
\hline \multicolumn{1}{c}{ Kelompok } & \multicolumn{1}{c}{$\mathbf{1}$} & \multicolumn{2}{c}{ Tikus ke } & \multicolumn{1}{c}{$\mathbf{2}$} & \multicolumn{1}{c}{$\mathbf{5}$} \\
\hline Kontrol & TAP & TAP & TAP & TAP & TAP \\
EEBMD $85 \mathrm{mg} / \mathrm{KgBB}$ & MFRPD, & MFRPD & FRDP, & FRPD & FRPD \\
& FRP, DH ++ & & DH++ & & \\
EEBMD $170 \mathrm{mg} / \mathrm{KgBB}$ & MFRPD & MFRPD, & MFRPD & MFRP & MFRP \\
& & MRFP & & & \\
EEBMD $340 \mathrm{mg} / \mathrm{KgBB}$ & FRPD & FRPD & Nekrosis sel & Nekrosis sel & FRPD \\
& & & hepatosit & hepatosit & \\
NEEBMD $85 \mathrm{mg} / \mathrm{KgBB}$ & MFRP & MFRP & FNP & TAP & MFRP \\
NEEBMD $170 \mathrm{mg} / \mathrm{KgBB}$ & TAP & TAP & MFRP & MFRPD & MFRPD \\
NEEBMD 340 mg/KgBB & MFRPD & TAP & MFRPD & TAP & MFNP, \\
& & & & & MFRP \\
\hline
\end{tabular}

\footnotetext{
Keterangan :

TAP : Tidak ada perubahan spesifik pada struktur sel penyusun jaringan/organ (normal)

FNP/MFNP : Foki/multifokal nekrotik di parenkim, ditandai adanya area nekrosis yang ditandai adanya kematian sel (inti mengalami kariopiknosis, sitoplasma hipereosinofilika) disertai infiltrasi limfosit di area nekrosis.

FRPD/MFRPD : Foki/multifokal radang di sekitar pembuluh darah, ditandai adanya infiltrasi limfosit dan neutrofil di sekitar pembuluh darah.

DH : Degenerasi hidropik, tampak adanya vakuola-vakuola berbatas tidak jelas dalam sitoplasma dan inti masih tampak di tengah.
}
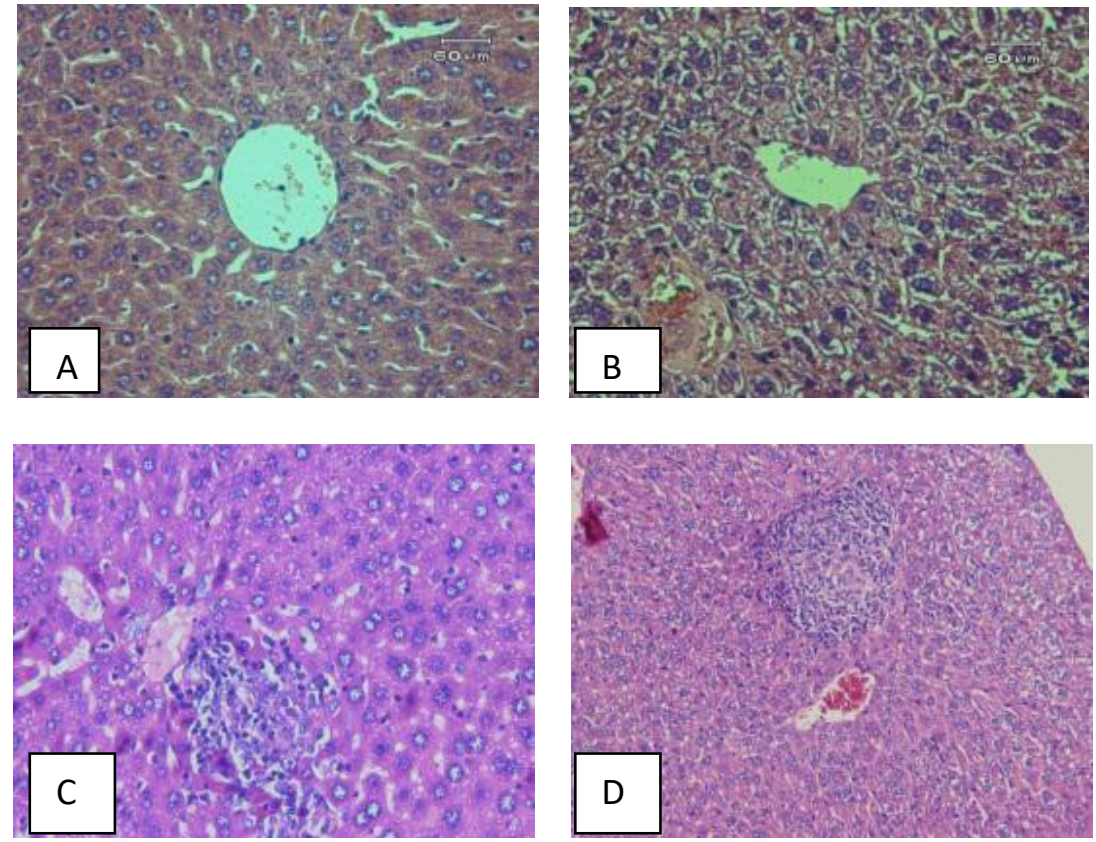

Gambar 2. Histopatologik hepar $\mathrm{A}=$ sel normal (kelompok kontrol); $\mathrm{B}=$ mengalami degenerasi sel hidropik (kelompok EEMD $85 \mathrm{mg} / \mathrm{KgBB}$ ) ; $\mathrm{C}=$ terdapat infiltrasi sel radang di sekitar vena centralis; $\mathrm{D}=$ sel hepar di daerah perifer mengalami lisis dan terdapat infiltrasi sel radang di sekitar vena centralis, dengan pengecetan $\mathrm{HE}$ dilihat menggunakan perbesaran 400x 
metabolisme obat adalah induksi enzim, inhibisi enzim, polimorfisme genetik, enzim pengasetilasi, dan usia (Neal, 2005). Keadaan fisik mencit sebelum diberi perlakuan juga sangat menentukan yaitu sistem imun, asupan dan lingkungan tempat tinggal mencit sebelumnya.

Pada gambar 2A yaitu kelompok kontrol terlihat sel hepatosit yang masih normal. Bentuk inti sel masih bulat penuh, sedangkan pada gambar $2 \mathrm{~B}$ terlihat banyak sel yang berwarna biru dan bentuk selnya pun sudah tidak berbentuk bulat penuh, hal ini menunjukkan adanya degenerasi hidropik. Pada degenerasi ini tampak vakuola yang berisi air dalam sitoplasma yang tidak mengandung lemak atau glikogen, sitoplasmanya menjadi pucat dan membengkak karena timbunan cairan. Perubahan ini umumnya merupakan akibat adanya gangguan metabolisme seperti hipoksia atau keracunan bahan kimia. Apabila penyebab cederanya menetap, sel yang telah cedera bisa mengalami robekan membran plasma dan perubahan inti sel sehingga sel mati atau nekrosis (Kumar,1999).

Pada gambar 2C kelompok ekstrak etanol buah mahkota dewa dengan dosis 340 $\mathrm{mg} / \mathrm{KgBB}$ terlihat adanya infiltrasi sel radang di sekitar venta sentralis. Menurut Anderson (1995) infiltrasi sel radang merupakan salah satu ciri-ciri akan terbentuknya radang. Peradangan sel merupakan reaksi vaskuler yang hasilnya merupakan pengiriman cairan, zat-zat terlarut dan sel-sel dari sirkulasi darah ke jaringan interstisial pada daerah cedera atau nekrosis.Inflamasi ditandai dengan perpindahan cairan protein plasma dan leukosit dari sirkulasi darah menuju ke jaringan sebagai respon terhadap bahaya.

Pada gambar 2D terlihat sel hepatosit terlihat adanya sel yang mengalami lisis. Lisis merupakan respon inflamasi setelah mengalami nerkrosis (Lumongga, 2008). Hal ini merupakan jejas irreversibel atau kematian sel.

\section{KESIMPULAN}

Tidak ada perbedaan signifikan pada perilaku/gejala fisik pada kelompok hewan uji yang diberi perlakuan ekstrak etanol buah mahkota dewa dengan kelompok mencit yang diberi nanopartikel buah mahkota dewa. Terdapat peningkatan rasio berat organ pada kelompok ekstrak etanol buah mahkota dewa dibandingkan dengan kelompok nanopartikel ekstrak etanol buah mahkota dewa. Berdasarkan gambaran histopatologik hepar, ketoksikan subkronis nanopartikel ekstrak etanol buah mahkota dewa terhadap mencit jantan galur Balb-c terdapat adanya penurunan kejadian ketoksikan pada hepar yang dibuktikan dengan nilai probabilitas mencit normal sebesar $\pm 0,4$ dari sejumlah hewan uji yang ada.

\section{DAFTAR PUSTAKA}

Anderson, P.S., 1995, Patofisiologi: Konsep Klinik Proses-Proses Penyakit. Alih Bahasa Peter Anugerah, Jakarta : CV. EGC Penerbit Buku Kedokteran, hal 51.

Biazar, E., Rezayat, S.M., Montazaeri, N., Pourshamsian, K., Zeinali, R., Asenejad, A., Rahimi, M., Zadehzare, M., Mahmoudi, M., Mazinani, R., dan Ziaei., M., 2010. The Effect of Acetaminophen Nanoparticles on Liver Toxicity in a Rat Model, International Journal of Nanomedicine, 5 : 197-201. 
Napsah, R dan Wahyuningsih, I., 2014, Preparasi Nanopartikel Kitosan-TPP-Ekstrak Etanol Daging BuahMahkota Dewa dengan Metode GelasiIonik, Jurnal Farmasi Sains dan Komunitas, ISSN : 1693-5683, Vol 11, No.1

Katno dan Pramono, S., 2004, Tingkat Manfaat Dan Keamanan Tanaman Obat Dan Obat Tradisional, Balai Penelitian Tanaman Obat Tawangmangu, Tawangmangu.

Kumar RC, Dasar Patologi penyakit, edisi 5, Jakarta:EGC, 1999, halaman 509-515.

Lumongga, F., 2008, Struktur Liver, http://repository.usu.ac.id bitstream/handle/123456789/2052/09E01467.pdf?sequence=1

Mardliyati.E, El Muttaqien. S , R Setyawati. D, Rosidah.I., dan Sriningsih, 2012, Preparasi Dan Aplikasi Nanopartikel Kitosan Sebagai Sistem Penghantaran Insulin Secara Oral, Pusat Teknologi Farmasi dan Medika BPPT, Jakarta Pusat.

Michael, B., Yano, B., Sellers, R.S., Perry, R., Morton, D., Roome, N., Johnson, J.K. dan Schafer, K., 2007, Evaluation of Organ Weights for Rodent and Non-Rodent Toxicity Studies : A Review of Regulatory Guidelines and A Survey of Current Practice, Toxicology Phatology, 35, 742-750.

Mohanraj, VJ. dan Chen, Y., 2006, Nanoparticles - A Review, Tropical Journal Pharmaceutical Research, 5(1): 561-573.

Mudahar, H., Lelly, W., dan, Sinta,D., 2005, Uji Sitotoksik Fraksi Etanol Buah Mahkota Dewa terhadap Sel Kanker Cerviks, Jurnal Bahan Alam Indonesia, 4(2): 275-279.

Neal, M.J., 2005 Medical Pharmacology at a Glace, diterjemahkan oleh dr. Juwalita, Jakarta, Penerbit Erlangga, halaman 14-15.

Radji, M., Sari, R.C., dan Sumiati A., 2008, Uji Aktivitas Antimikroba dan Uji Sitotoksik Ekstrak Etanol Akar Tanaman Akar Kucing (Acalypha indica Linn.), Daging Buah Mahkota Dewa (Phaleria macrocarpa (Sheff) Boerl.) dan Sari Buah Merah (Pandanus conoideus Lam), Majalah Ilmu Kefarmasian, 5(I): 40-46.

Rohyami, Yuli, 2008, Penentuan Kandungan Flavonoid dari Ekstrak Metanol Daging Buah Mahkota Dewa (Phaleria macrocarpa scheff.boerl., Jurnal Logika, 5(1).

Soeksmanto, A., 2006. Pengaruh Ekstrak Butanol Buah Tua Mahkota Dewa (Phaleria macrocarpa) Terhadap Jaringan Ginjal Mencit (Mus musculus), Biodeversitas, 7(3): 278-281.

Sulistianto, DE., Harini M., Handajani NS., 2004, Pengaruh pemberian ekstrak buah mahkota dewa [Phaleria macrocarfa (Scheff) Boerl] terhadap 4 struktur histopatologis hepar tikus (Rattusnorvegicus L.) setelah perlakuan dengan karbon tetraklorida (CC14) secara oral, Skripsi, Biologi FMIPA Universitas Sebelas Maret, Surakarta.

Thoolen, B., Maronpot, R.R., Harada, T., Nyska, A., Rousseaux, C., Nolte, T., Malarkey, D.E., Kaifmann, W., Kuttler, K., Deschl, U., Nakar, D., Gregson, R., Vinlove, M.P., Brix, A., Singh, B., Belpoggi, F., dan Ward, J.M., 2010, Proliferation and Nonproliferative Lesion of the Rat and Mouse Hepatobiliary System, Toxicologic Pathology, 38: 55-815.

Utomo, Y., Hidayati, A., Dafip, M., dan Sazi, F.A. Studi Histopatologi Hati Mencit (Mus Musculus L.) yang Diinduksi Pemanis Buatan. Jurnal MIPA, 35(2). 